\title{
Modularization Construction and Practical Research on Curriculum System of Product Design in Colleges under the Background of "Internet + Education"
}

\author{
Dan Chang \\ Changchun Sci-Tech University, Jilin, Changchun, 130600
}

Keywords: Internet + Education, Curriculum System, Modular, Product Design Professional.

\begin{abstract}
Today's Chinese education has been fully into the Internet era, reflected in all aspects, whether it is economic, business or education are inseparable from the Internet. Internet + education, is undoubtedly the current education should be the most should solve the problem. Higher education institutions after graduation is to face the community, so the education of the comprehensive, scientific and technological, information, and social development must be consistent. This article mainly for the university product design professional curriculum system innovation, the implementation of "Internet + education" curriculum modular settings. This setting can solve student problems for different stages and different needs, and can learn the knowledge learned during the internship, advance into the classroom to solve. Effectively improve the students professional practice ability for future employment to provide a higher protection.
\end{abstract}

\section{Introduction}

"Internet + education" is the development trend of today's institutions. Means that the Internet into the classroom, rather than the Internet refused to the classroom outside the door. In view of the professional characteristics of product design, "Internet + education" through the modular reform of the curriculum system, the different curriculum model into the classroom teaching. Product design professional development of the "Internet + education" curriculum system module, mainly divided into such as: "Internet + theory" course module, "Internet + practice" course module, "Internet + training project" course module, three modules. To a wide range of multi-angle, comprehensive coverage of product design professional curriculum system construction and practice.

\section{The product design professional "Internet + education" curriculum system modular construction}

"Internet + education" curriculum system module is to change the traditional curriculum. The network era of convenience and massive information resources into the product design professional curriculum system module. Mainly embodies three aspects: First, "Internet + theory" course module, the second is "Internet + practice" course module, the third is "Internet + training project" course module. The Internet in many ways, multi-angle comprehensive coverage, the full introduction of the teaching content of the students, and "true, practice, training," the three constitute the system, followed by combat classroom. For the Internet is the latest information and traditional knowledge integration; the use of the Internet a strong amount of resources and market direct convergence. With the Internet platform, to achieve high-quality curriculum resources sharing, so as to stimulate students to self-learning, improve the effectiveness of student learning.

"Internet + theory". The course module is actually a gospel for students. Can be taught in the theory of product design professional theory, through the theory of network learning theory, is based on the traditional constructivist theory, for the network era of learning the two major challenges information overload and knowledge fragmentation and put forward a set of methods and Strategy. In addition to the use of connectivity strategy, but also learn to choose, for their own interests and 
needs of close information and knowledge, to be strong connectivity and depth of construction. Information and knowledge fragmentation organic integration together to build a complete personalized knowledge system, and ultimately to achieve knowledge innovation.

"Internet + practice". Course modules and previous teaching courses are different, pay more attention to the link with real life. The main design direction of the product design profession is closely related to people's daily necessities. This course module settings just follow this link, the daily necessities and design and construction, the formation of an effective demand chain, the practical ability to have a greater improvement.

"Internet + training program". The course module can meet the students' design of the whole process of product design. Product design and manufacture of the entire cycle are: "customer needs - information collection - creative - design - production - processing - model - proofing - finished sales - feedback" and other training sessions. Focus on three areas: a. Design areas: the establishment of "Internet +", the industry chain, from creative design to proofing the formation of an independent market, so as to improve the design of the product's practicality and functionality. b. Production areas: Through the status and work of intelligent manufacturing, students can broaden the professional basis, employment-oriented, high-end skills for the training direction, increase the ability of graduates to adapt to industrial development. c. sales areas: pay more attention to the late product promotion and purchase, to solve the market, whether it is consumer trustworthy products.

\section{The "Internet + education" product design professional curriculum system modular practice teaching}

"Internet + theory" course modules in the practice of teaching before the class, the teacher can be published through the network platform pre-class preview of the students and the corresponding test. Students learn micro-class and answer, after submitting the answer, the teacher will be able to see each student answer situation. Teachers through the graphics can be intuitive and very accurate understanding of what knowledge of students who know better, which knowledge points also need to further explain, in order to achieve the purpose of the first study, improve classroom efficiency.

The use of "Internet + practice" curriculum module, from the Internet to search for relevant information to learn, organize everyone from the perspective of teaching design analysis and discussion; in the discussion of micro-class, flip the classroom, requiring students to learn micro-class production, Practice, exchange discussion. So that students in the classroom to share their new knowledge from the Internet to learn new skills. Teaching content can be flexible, the students can also be the first time to grasp the market dynamics, to complete the different abilities and design requirements, can teach, discuss, flip, practice, get a good exercise, you can directly through the case of field visits and needs analysis.

In the "Internet + training project" module, mainly for students to complete the project case design work independently, from the previous research, creation, production, sales and other aspects of comprehensive training. So that students can not learn the campus, as a mature designer should have the design capacity and quality. This course set, only the "Internet + " digital information age can be achieved, the use of the Internet a strong amount of resources and market direct convergence, so as to achieve the ultimate teaching effect.

Internet and real life to contact us more and more closely, the network for us to obtain a variety of information and resources to provide a great convenience. Teaching content is no longer rigidly adhere to the textbooks and outline, but based on teaching materials, outline as a clue, from the network and life practice to find real material, real case teaching. Therefore, "Internet + education" is to build product design professional and practice the most effective, new curriculum system settings. 


\section{Acknowledgements}

Jilin Province, education science "thirteen five" planning general issues, "' Internet + education "under the background of the university product design professional curriculum system modular construction and practice research", subject approval number GH170979.

\section{References}

[1] Dong Yangde, "Internet + training" teaching model reform exploration, "occupation", 201536

[2] Qiao Jianyong, with the spirit of the Internet to promote teaching reform, China Education News Network - China Education News, 2016.07.08

[3] forestry, "Internet +" era of education and teaching reform reasons and breakthroughs, "new curriculum (below)" 201507 